\title{
Identifikace rybníků v povodí Blanice na mapách I. rakouského vojenského mapování
}

\section{VÁCLAV DAVID, KATEŘINA ČERNOCHOVÁ}

\author{
Klíčová slova: rybník - staré mapy - I. rakouské vojenské mapování - identifikace - Blanice
}

\section{SOUHRN}

Článek se zabývá identifikací rybníků zakreslených na mapách I. rakouského vojenského mapování. Prezentované analýzy jsou založeny převážně na manuální práci se starými mapami, jelikož použité mapové dílo postrádá přesnost a podrobnost potřebnou pro automatizované zpracování v prostředí GIS. Zájmovou oblastí prezentované studie je povodí Blanice o rozloze 543,3 km² nacházející se ve Středočeském kraji 50 km jihovýchodně od Prahy. V rámci analýz byla bodově identifikována poloha každého rybníka zakresleného na mapách 1. rakouského vojenského mapování nad současnými mapami. $\checkmark$ povodí bylo identifikováno celkem 818 rybníků, z nichž 430 zůstalo zachováno do současnosti. Výsledkem zpracování je bodová vrstva rybníků zakreslených na mapách I. rakouského vojenského mapování ve formátu ESRI shapefile s atributy přesnosti určení polohy a zachovalosti tělesa hráze.

\section{ÚVOD}

Rybníky se podílí na formování krajiny na území současné České republiky již více než tisíc let, přičemž jejich existenci Ize doložit již v 10. století, někteří autoři (např. Míka [1]) dokonce odhadují existenci prvních rybníků i do dřívějších období. O tom, jak dlouho již na našem území rybníky obecně existují, tedy představu máme. $V$ současnosti se jejich celkový počet odhaduje na cca 23-24 tisíc [2, 3], přičemž toto číslo je spíše orientační, protože vždy závisí na tom, co je za rybník považováno. Stárí rybníků je velmi rozdílné, ovšem většina z nich pochází z takzvaného zlatého věku rybnikářství, který je zpravidla vymezován jako období zahrnující poslední čtvrtinu 15. století a první polovinu 16. století $[1,4]$. Podrobnější znalosti o stárí rybníků však v širším měřítku chybí. U těch nejvýznamnějších je zpravidla období výstavby známo. Př́kladem mohou být například největší existující rybník v České republice Rožmberk (dokončen 1590 [5]) nebo Máchovo jezero (dokončen 1272 [5]). Naproti tomu např́klad u největšího rybníka na Moravě Nesytu není rok dokončení znám a jednotlivé prameny se $v$ dataci vzniku rozcházejí. Některé zdroje uvádí původ v 16. století [5], správnější však bude datace mezi roky 1514 a 1518 na základě informací z urbáře a dalších listin [6]. Obecně je informace o době založení a tedy stáři jednotlivých rybníků spíše nedostupná. Z mnoha důvodů však je alespoň přibližná informace tohoto typu velmi důležitá. V prípadě jednotlivých rybníků je možné pátrat $v$ archivních materiálech a kronikách, pokud však jde o mapování historie rybníků v rámci většího území, je tato cesta dosti náročná. Jednou z možností, jak získat povědomí o historickém výskytu rybníků v nějaké oblasti, je využití starých map. V tomto ohledu je ovšem nutno poznamenat, že s narůstajícím stárím map klesá jejich polohová přesnost.

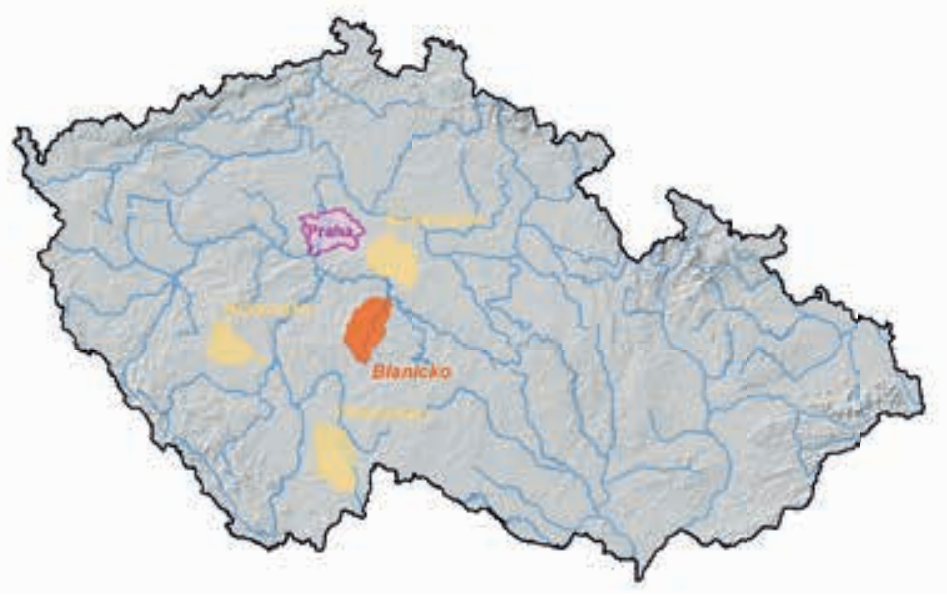

Obr. 1. Poloha zájmového území - povodí Blanice

Fig. 1. Location of the study area - catchment of Blanice River

Využití starých map pro mapování historických rybníků není zcela nové. $\checkmark$ nedávném období bylo provedeno kompletní zmapování rybníků a vodních ploch zakreslených na mapách II. vojenského mapování, které probíhalo na území České republiky v letech 1819-1858 [7]. Použité mapové podklady mají poměrně vysokou polohovou presnost a s ohledem na identifikaci vodních ploch a digitalizaci jejich rozsahu i uspokojivou podrobnost. Výsledkem tohoto mapování je vrstva všech rybníků a vodních ploch s rozlohou nad 0,5 ha zakreslených na zmíněných mapách [8]. Tato vrstva byla jedním z podkladů použitých pro knihu Historické rybníky České republiky vydané v roce 2014 [9]. Mapy II. rakouského vojenského mapování ovšem byly vytvořeny po jedné z největších vln rušení rybníků související zejména se společenskými a hospodářskými změnami v období vlády Marie Terezie a Josefa II. [6, 10]. Z toho důvodu nezachycují řadu rybníků, jelikož jich bylo mnoho před tímto mapováním zrušeno. $\checkmark$ návaznosti na dřive realizované výzkumy orientované na mapy II. rakouského vojenského mapování tak bylo žádoucí jít hlouběji do minulosti a zabývat se analýzou map I. rakouského vojenského mapování. Ty byly zpracovány pro oblast Čech v letech 1764-1768, v letech 1780-1783 pak proběhla jejich rektifikace, prípadně nové mapování [11, 12]. Využití map I. rakouského vojenského mapování pro výzkum vývoje vodních ploch není zcela nové. $\vee$ minulých letech byly analýzy tohoto typu realizovány pro povodí Bystřice, Jevišovky a Opavy s cílem identifikace zaniklých rybníků s potenciálem obnovy [13]. Jednalo se však o identifikaci rybníků většího rozsahu, jelikož analýzy byly prováděny predevším za účelem posouzení potenciálu obnovy. $V$ prípadě analýz prezentovaných v tomto článku se ovšem jedná především o vytvoření podkladu pro hodnocení 
historického vývoje vodních ploch, přičemž cílem bylo zjistit celkové množství rybníků vyskytujících se v době zpracování použitého mapového díla v zájmovém území. Jedním z dalších cílủ bylo také identifikovat rybníky zaniklé pro získání informace o úbytku vodních ploch na přelomu 18. a 19. století. Budování malých vodních nádrží je uvažováno jako jeden z prostředků zvyšování retence vody $\vee$ krajině a boje se suchem a znalost polohy zaniklých rybníků může být $v$ tomto směru užitečným podkladem, byt je nutno podotknout, že při plánování výstavby malých vodních nádrží k uvedenému účelu je zapotřebí posoudit všechny její možné dopady na hydrologický režim i další aspekty.

Identifikace byla v první fázi testována pro povodí Blanice, která je levostranným př́tokem Sázavy, do níž se vlévá u Českého Šternberka. Jedná se o jednu ze čtyř oblastí, které jsou předmětem zkoumání v rámci projektu DG16P02M036 „Údržba, opravy a monitoring hrází historických rybníkủ jako našeho kulturního dědictví" [14]. Povodí se nachází jihovýchodně od Prahy (viz obr. 1), má rozlohu 543,3 km² a jeho hydrografická sít je tvořena Blanicí, jejím hlavním levostranným prítokem Chotýšankou a řadou menších přítoků těchto toků.

\section{METODIKA}

Mapy I. rakouského vojenského mapování mají ve srovnání s mapami pozdějšími mnohem menší polohovou presnost. Od toho se odvijí i způsob, kterým bylo nutno je analyzovat. Ten spočíval v tom, že pro každý rybník zakreslený na těchto mapách byla identifikována jeho poloha v současných mapových podkladech v prostředí GIS.

Rybníky zakreslené na mapách I. vojenského mapování byly mapovány $\checkmark$ několika ohledech:

— v prípadě dosud existujících rybníků byla zaznamenávána existence v období 1764-1768 (existence byla předpokládána v prípadě zakreslení rybníka v mapě I. rakouského vojenského mapování),

- u rybníků, které se do současnosti nezachovaly, byla klasifikována identifikovatelnost a patrnost hráze $v$ současném terénu,

— u relativně dobře identifikovatelných rybníků, které se do současnosti nedochovaly, byl prováděn přibližný zákres na základě současné topografie.

V první fázi byly prozkoumávány mapy s ohledem na pouhou identifikaci rybníků zachycených na mapách I. rakouského vojenského mapování, a to jak s ohledem na rybníky dosud existující, tak ty již zaniklé. Identifikace byla prováděna tak, že pro každý rybník zachycený na staré mapě byla provedena identifikace na současných mapách. Postup byl takový, že nejprve byl na mapě

Tabulka 1. Kategorie identifikovatelnosti rybníkü zakreslených na mapách I. rakouského vojenského mapování

Table 1. Categories of identification accuracy of fishponds depicted on maps of 1st Austrian Military Survey

\section{Kategorie Popis}

poloha určena velmi přesně, vyznačený bod se určitě nachází v prostoru zátopy historického rybníka (platí 1 zejména u rybníků dosud existujících a zaniklých rybníků, u kterých je dosud zachována hráz)

2 poloha určena méně přesně, bod se nejspišse nachází v prostoru zátopy historického rybníka

3 poloha určena se značnou mírou nejistoty, rybník se nacházel nejspíše v místě bodu či jeho blízkosti

poloha určena pouze orientačně, rybník se někde v okolí bodu nacházel

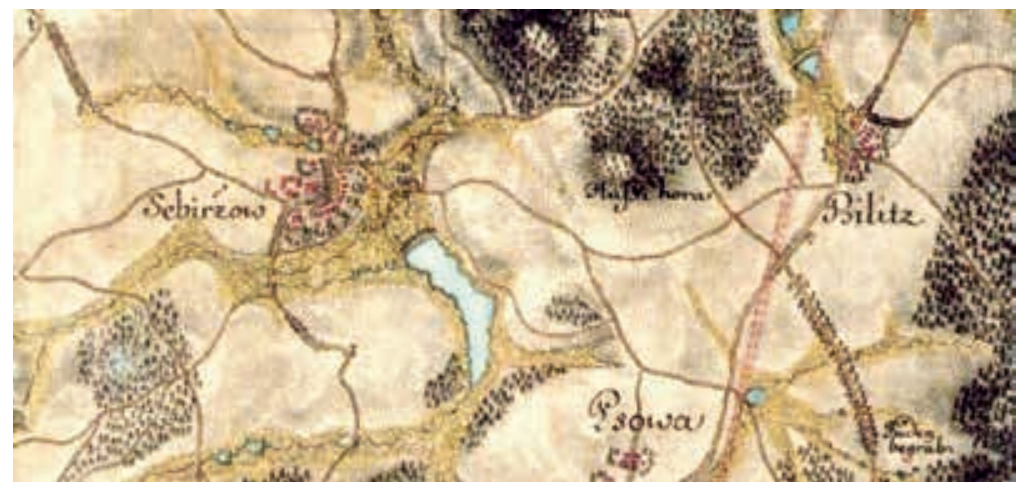

Obr. 2. Rybník východně od obce Šebir̂ov na mapě I. rakouského vojenského mapování Fig. 2. Fishpond east of village Šebiriov captured on map of ${ }^{\text {st }}$ Austrian Military Survey

I. rakouského vojenského mapování vybrán rybník, a následně byla jeho poloha hledána nad současnými mapovými podklady. Následně byla ještě provedena konfrontace s mapami II. a III. rakouského vojenského mapování. Místo bylo označeno bodem a následně mu byly přiřazeny dva atributy - přesnost identifikace a existence hráze. Oba uvedené atributy mají formu kategorií, jejichž podrobný popis je uveden v tabulkách 1 a 2.

$\checkmark$ prípadě identifikace polohy na současných mapách bylo použito několika hlavních indikátorů. $V$ prvé řadě byl identifikován tok, na němž se rybník nacházel. Dále byly identifikovány prítoky, které se v jeho blízkosti nacházely, nedaleké obce a významné terénní útvary (především vrcholy kopců). Dalším významným podkladem byla podrobná výškopisná data a z nich odvozený stínovaný model reliéfu. Konkrétně byla využita vrstva Digitálního modelu reliéfu 5. generace (DMR5G) dostupná jako ArcGIS služba na portálu http://ags. cuzk.cz/arcgis2/services/dmr5g/ImageServer. Tento podklad byl důležitý především s ohledem na klasifikaci existence pozůstatků hráze, užitečný byl však i pro prvotní identifikaci polohy.

U větších rybníků byla identifikace zpravidla poměrně snadná, v některých prípadech nebylo nutno lokalizaci provádět, protože rybníky byly zakresleny ve vrstvě digitalizovaných vodních ploch zachycených na mapách II. rakouského vojenského mapování [15]. Na obr. 2 je znázorněn rybník zakreslený na mapě I. rakouského vojenského mapování v blízkosti obce Šebírov (okr. Tábor). V současnosti se v těsné blízkosti obce rybník nenachází, je však zachycen právě ve vrstvě digitalizovaných vodních ploch z map II. rakouského vojenského mapování (viz obr. 3 se zobrazeným polygonem rybníka ze zmiňované vrstvy nad Základní mapou ČR).

Tabulka 2. Kategorie existence pozůstatků hráze v současnosti Table 2. Categories of dam remains existence at present

\section{Kategorie Popis}

\begin{tabular}{ll}
\hline 0 & neřešeno - rybník stále existuje \\
\hline 1 & v terénu je v současné době patrná velká část hráze \\
\hline 2 & $\begin{array}{l}\text { v terénu je v současné době patrná velká část hráze } \\
\text { panelová) }\end{array}$ \\
\hline 3 & $\begin{array}{l}\text { v terénu je } v \text { současné době patrná velká část hráze a vede } \\
\text { po ní nezpevnéná komunikace (vč. štěrkových cest) }\end{array}$ \\
\hline 5 & v terénu je v současnosti patrná menší část hráze \\
\hline 6 & v terénu jsou v současnosti stopy existence bývalé hráze \\
\hline žádné stopy hráze nejsou v současnosti v terénu patrné
\end{tabular}



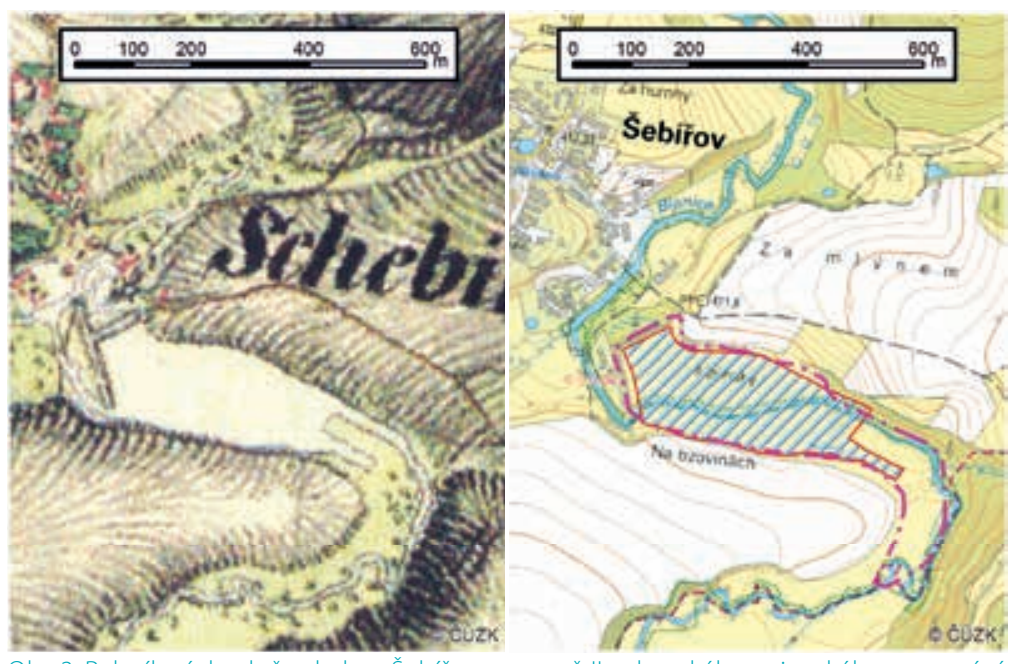

Obdobným príkladem jako v předchozím případě je rybník, který na mapě I. rakouského vojenského mapování nese název Lounjowitz Teich (Louňovický rybník) a nacházel se prímo na toku Blanice severně od Louňovic pod Blaníkem (viz obr. 4). Hráz tohoto rybníka zůstala zachována dodnes zejména proto, že po ní vedla a stále vede komunikace (viz obr.5), která překonává poměrně zaříznuté údolí Blanice. I tento rybník je patrný ještě na mapách II. rakouského vojenského mapování, zde je však zakreslen již mnohem menší rozsah zátopy (viz obr. 6). Na mapě III. rakouského vojenského mapování již vodní plocha znázorněna není.

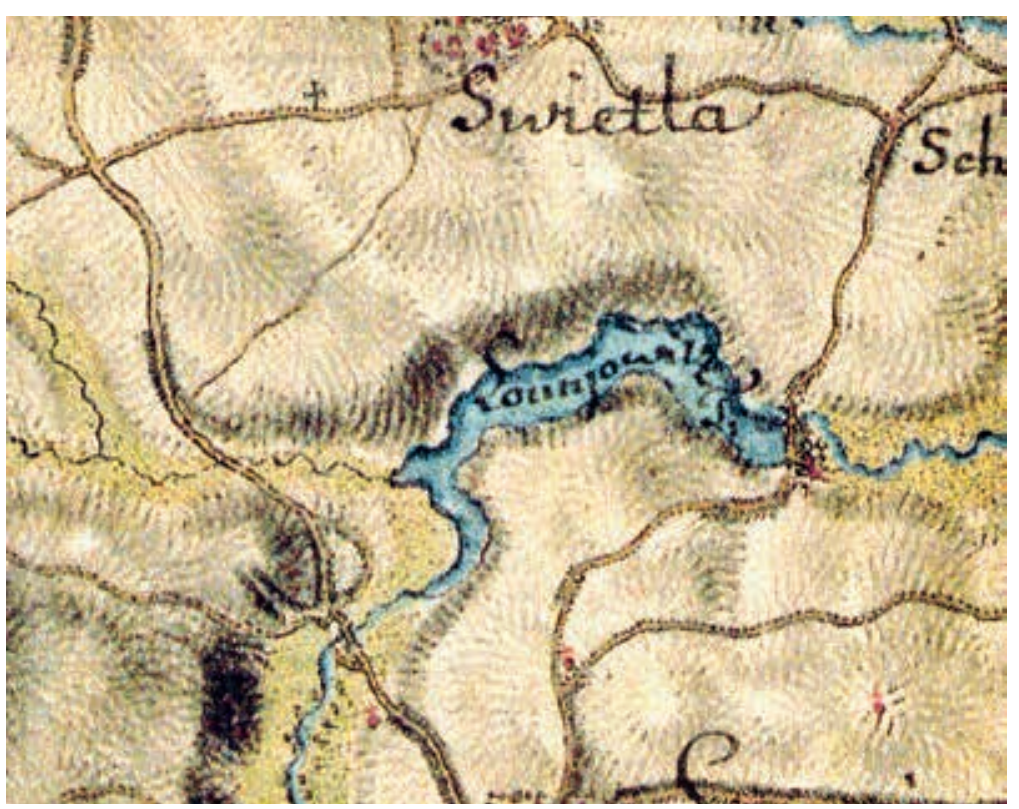

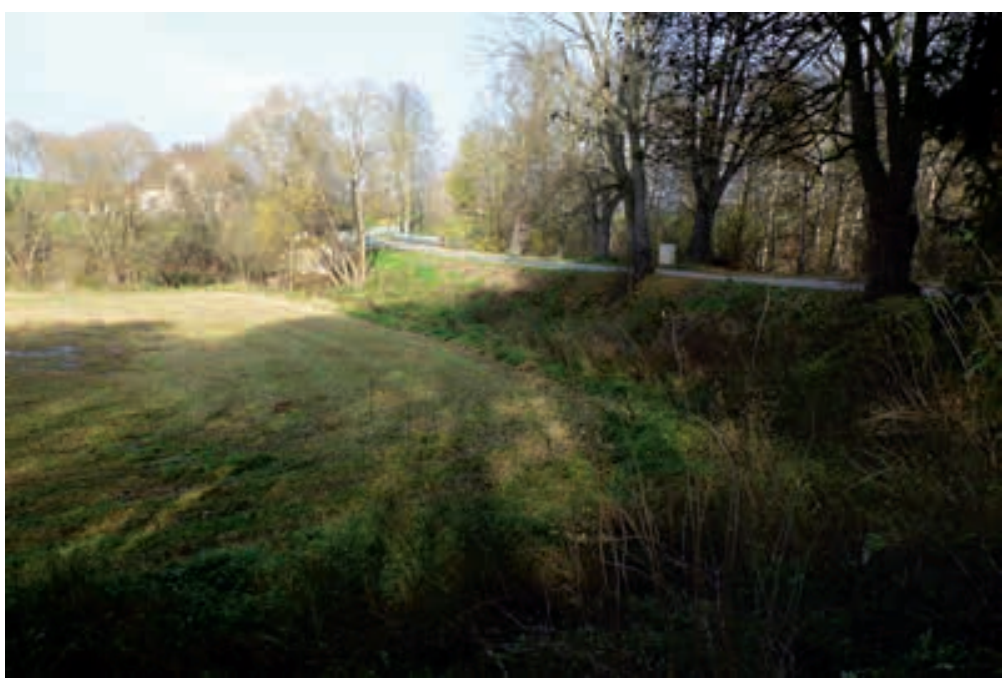

V prípadě menších rybníků, kterých je na mapách I. rakouského vojenského mapování zachyceno velké množství, byla situace jiná. S ohledem na způsob pořizování map je jejich polohová přesnost velmi malá a identifikace takovýchto rybníků je značně obtížná. V mnoha prípadech nezůstala s ohledem na její původní malou velikost zachována $v$ důsledku působení prírodních i antropogenních procesů ani hráz. Velmi dobrým príkladem této situace je soustava rybníků v okolí Křtěnovic. Na mapě I. rakouského vojenského mapování (viz obr. 7) je patrné, že se zde nacházela řada rybníků na samotném Křtěnovickém potoce i na jeho prítocích. Na mapách II. rakouského vojenského mapování i na současných mapách je rybníků zachyceno mnohem méně (viz obr. 8). Př́kladem zaniklého rybníka, u kterého je poloha dobře identifikovatelná, je rybník jižně od obce, jehož hráz zůstala do dnešní doby zachována, a je patrná na všech prezentovaných mapových podkladech. Na druhou stranu

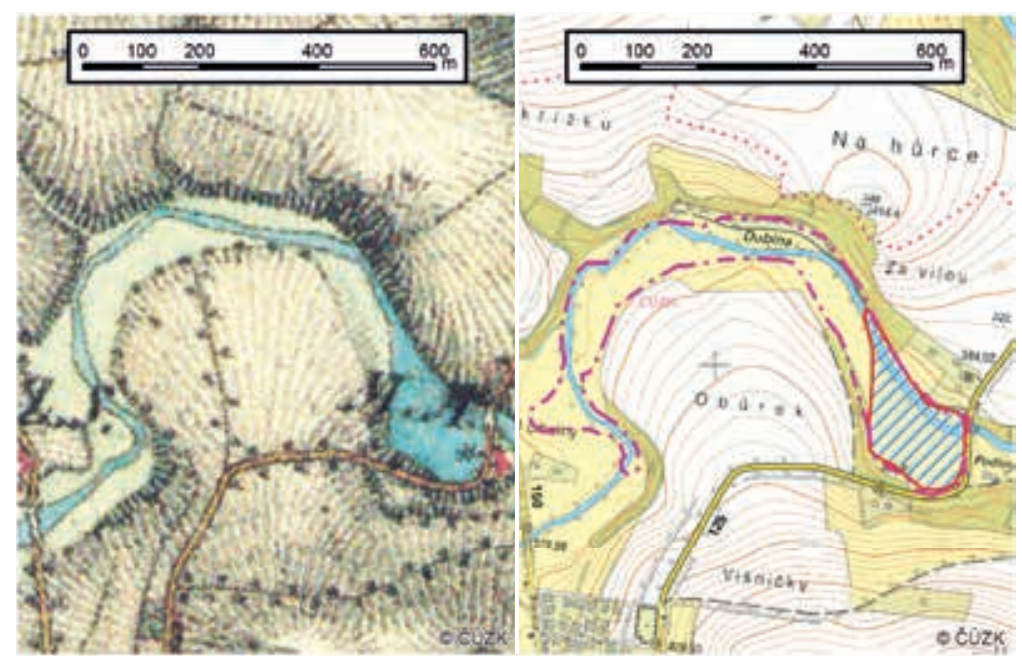


dva rybníky na levostranném prítoku, které se v minulosti nacházely pod tím, který se zachoval do současnosti, jsou s ohledem na polohu identifikovatelné velmi obtížně. Jediné, co je víceméně jisté, je, že tyto dva rybníky se nacházely na toku mezi rybníkem dochovaným a soutokem s Křtěnovickým potokem. Na mapě I. rakouského vojenského mapování je na levostranném prítoku zaznamenán ještě jeden rybník, který se nacházel nad rybníkem dochovaným dodnes. Jeho poloha je ještě obtížněji identifikovatelná, protože jej Ize vztahovat pouze k rybníku dochovanému a sedlem, od kterého vychází údolnice, $\checkmark$ níž se tok nachází. Obdobně je alespoň príbližně identifikovatelná poloha prostředního rybníka na pravostranném prítoku, jelikož níže položený rybník se dochoval a poloha výše položeného rybníka je identifikovatelná na mapě II. rakouského vojenského mapování.

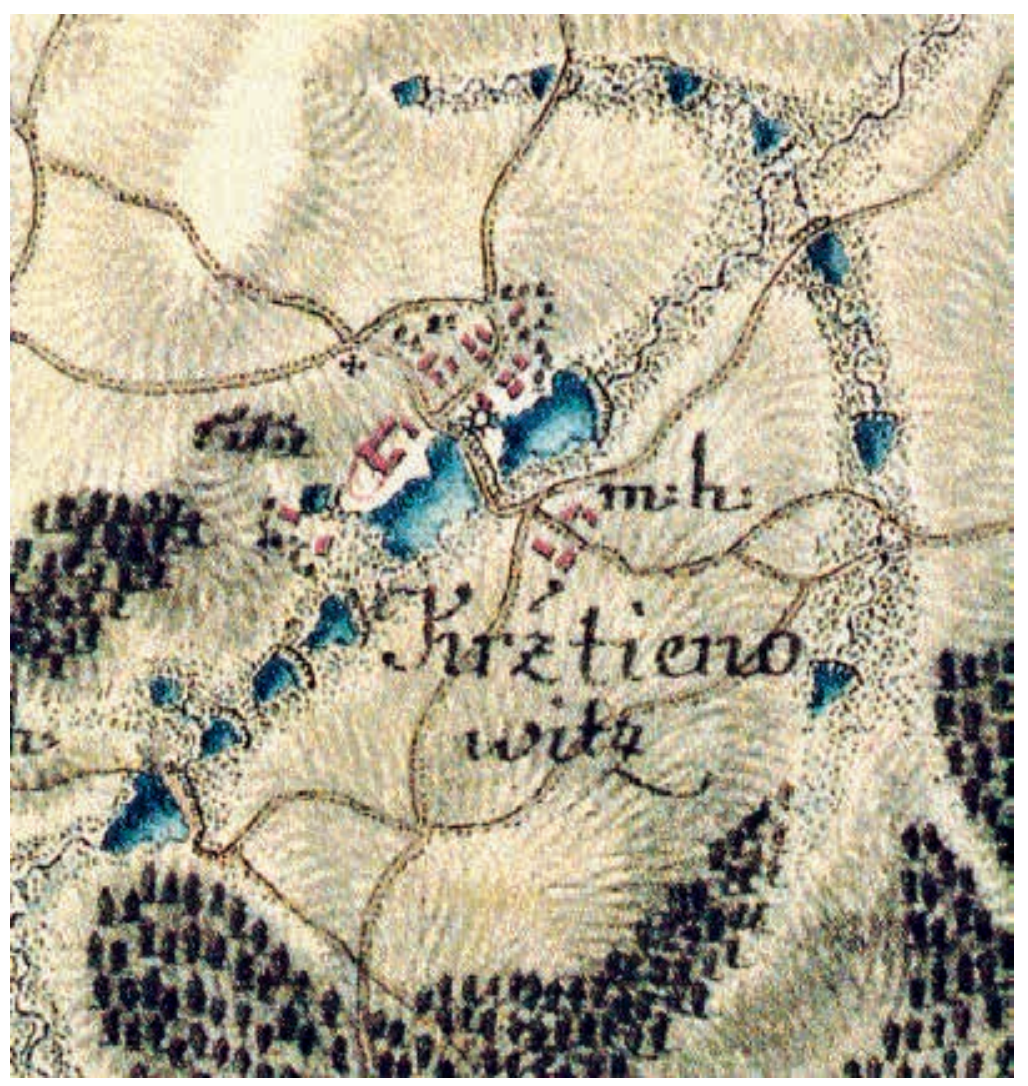

Obr. 7. Rybníky v okolí Křtěnovic zachycené na mapě l. rakouského vojenského mapování

Fig. 7. Fishponds in the vicinity of Křtěnovice captured on map of $1^{\text {st }}$ Austrian Military Survey

\section{VÝSLEDKY}

V povodí Blanice bylo z map I. rakouského vojenského mapování identifikováno celkem 818 rybníků a vodních ploch včetně těch nejmenších. $Z$ tohoto počtu se jich celkem 430 dochovalo v nějaké míre do současnosti. Zbylých 385 rybníků od období l. rakouského vojenského mapování zaniklo. Z celkového množství zaniklých rybníků jich bylo 89 lokalizováno jednoznačně, u ostatních byla jejich poloha identifikována s menší úrovní spolehlivosti. V př́padě 53 zaniklých rybníků byla na základě analýzy mapových podkladů nalezena celá původní hráz nebo její většina, u dalších 55 byly na podrobném modelu reliéfu identifikovány stopy hrází či jejich pozůstatky. Některé z těchto 55 rybníků byly kategorizovány do druhé třídy přesnosti určení polohy, nebot ne vždy bylo s jistotou možné určit, zda se skutečně jedná o pozůstatek tělesa hráze nebo o jiný terénní útvar.

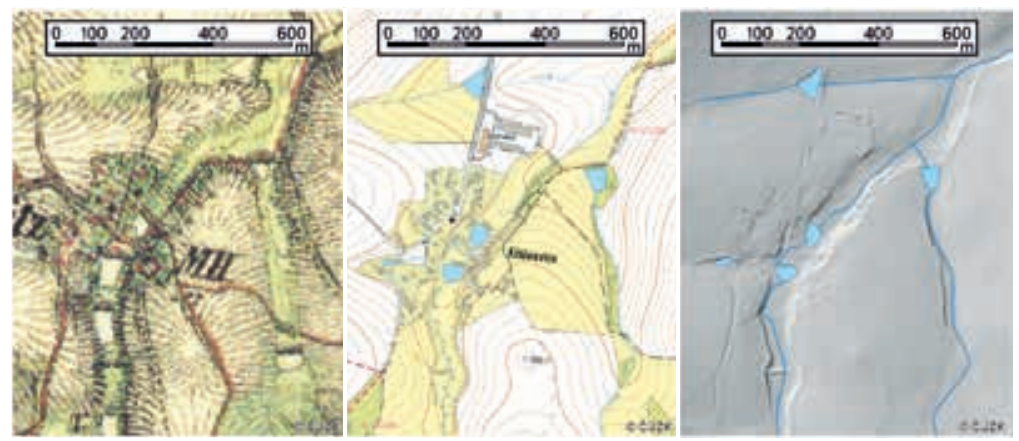

Obr. 8. Okolí Křtěnovic zachycené na mapě II. rakouského vojenského mapování (vlevo), na Základní mapě ČR (uprostřed) a na Digitálním modelu reliéfu 5. generace (vpravo) Fig. 8. The vicinity of Křtěnovice on map of $2^{\text {nd }}$ Austrian Military Survey (left), on Basic map of the Czech Republic (middle) and Digital Relief Model of $5^{\text {th }}$ Generation (right)

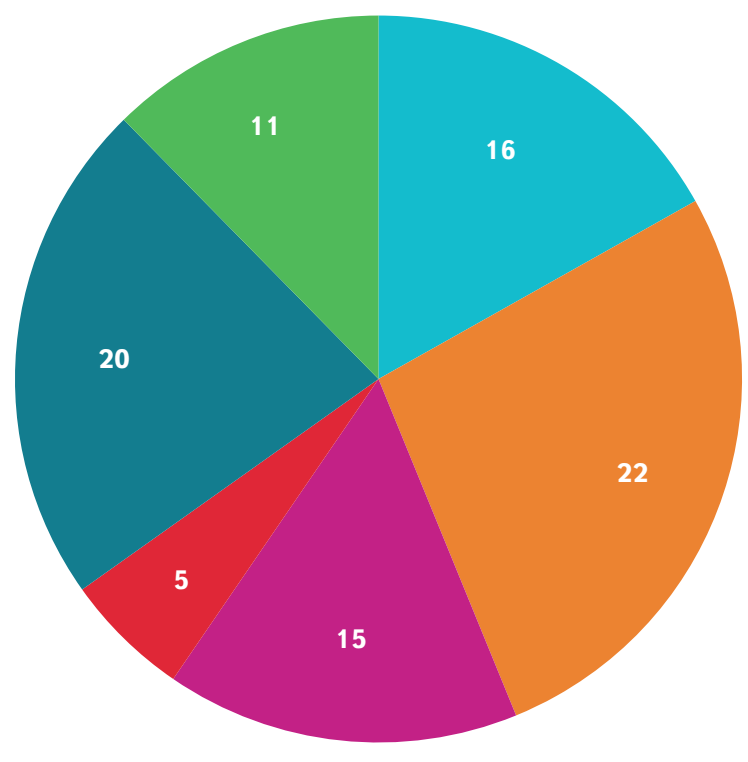

v terénu je v současné době patrná velká část hráze

v terénu je v současné době patrná velká část hráze a vede po ní zpevněná komunikace (asfaltová, betonová, panelová)

v terénu je v současné době patrná velká část hráze a vede po ní nezpevněná komunikace (vč. štěrkových cest)

v terénu je v současnosti patrná menši část hráze

v terénu jsou v současnosti stopy existence bývalé hráze

žádné stopy hráze nejsou v současnosti v terénu patrné

Obr. 9. Zastoupení kategorií identifikace hráze u zaniklých rybníků, které byly lokalizovány velmi přesně

Fig. 9. Frequency of dam existence categories for accurately identified extinct ponds

S ohledem na zastoupení jednotlivých kategorií zachovalosti hráze je zrejmé, že u přesněji lokalizovaných zaniklých rybníků je větší zastoupení těch, u nichž se zachovala hráz, jelikož její pozůstatky byly jedním z vodítek při lokalizaci. Naopak ve skupině rybníků, které byly lokalizovány pouze orientačně, nebyly identifikovány ani stopy původních hrází. Z pohledu zachovalosti hráze je proto zajímavé především zastoupení jednotlivých kategorií pro zaniklé rybníky, které byly identifikovány jednoznačně. Toto zastoupení je znázorněno v grafu na obr. 9. 
Dalším zajímavým výsledkem provedených analýz je prostorové rozmístění rybníků existujících v období II. rakouského vojenského mapování. Toto rozmístění v ploše povodí je znázorněno v mapě na obr. 10. Z mapy je patrné, že $v$ severovýchodní části povodí v blízkosti soutoku Blanice se Sázavou se $\checkmark$ minulosti nacházelo jen velmi malé množství rybníků. Výrazně nižší hustota vodních ploch v této části zájmového území je patrná i při pohledu na aktuální stav. Nejvyšší koncentraci rybníků pak Ize najít v jihozápadní části území na horním toku Chotýšanky a v povodí Slupského potoka.

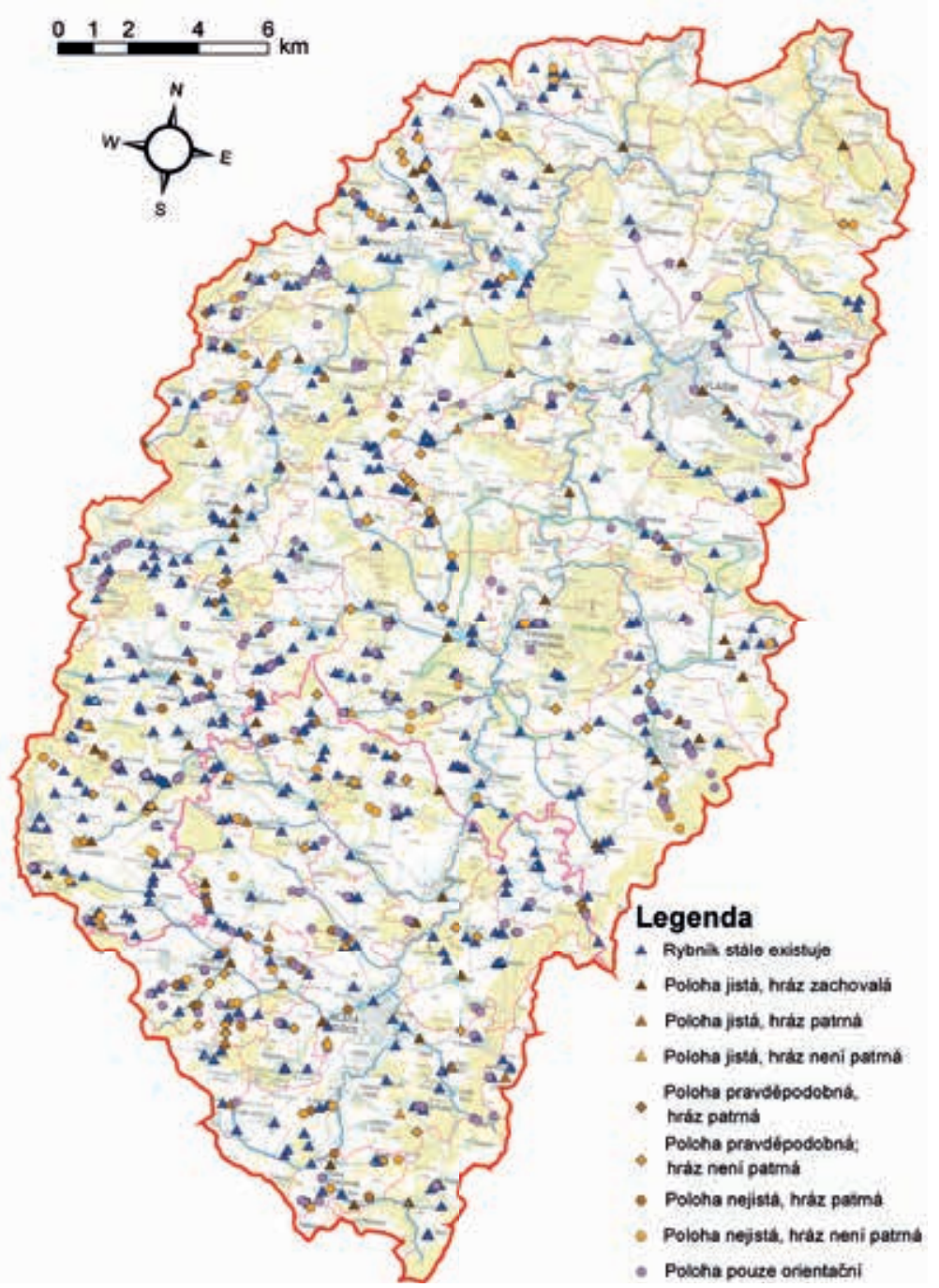

Obr. 10. Mapa rozmístění rybníků identifikovaných na mapách I. rakouského vojenského mapování

Fig. 10. Map of position of fishponds identified on maps of $1^{\text {st }}$ Austrian Military Survey

Při bližším pohledu na jednotlivá dílčí území je také patrná nerovnoměrnost rozmístění rybníků. Rybníky jsou často shluknuty v blízkosti sídel, což je pochopitelné s ohledem na potřebu dostupnosti při správě a využívání. Často se v území vyskytují kaskády rybníkủ (například na Zhořském nebo Křtěnovickém potoce) nebo celé soustavy (napríklad v okolí Jankova). Zajímavostí je též výskyt nebeských rybníků umístěných v sedlech. Jedním z nich je rybník nesoucí v současnosti jméno Mikuláš, který se nachází severozápadně od Mladé Vožice. Jeho současný rozsah je oproti tomu zaznamenanému na mapě l. rakouského vojenského mapování výrazně menší, když v minulosti měl hráz po obou stranách sedla a byl více než pětinásobný. Obdobně tomu bylo i u rybníka, který nese v současnosti název Suchý a který se nachází nedaleko západním směrem. Další takovéto rybníky se nacházely například mezi Jankovskou Lhotou a Stržencem v lokalitě V Boroví (v současnosti zachována pouze západní část) nebo v blízkosti Kaliště v lokalitě Kačiny (plocha bývalé zátopy je $v$ současnosti odvodňována z části Strženeckým potokem a z části bezejmenným pravostranným př́tokem Janovského potoka do Konopištškého potoka mimo zájmové území).

\section{ZÁVĚR}

Výsledky provedených analýz prezentovaných v tomto článku jsou především velmi vhodným podkladem pro výzkum dynamiky vývoje krajiny v zájmovém území. Použitý postup analýzy se ukázal jako poměrně zdlouhavý, s ohledem na vlastnosti použitého mapového díla ovšem asi jako jediný možný. S ohledem na skutečnost, že byly mapovány i nejmenší vodní plochy, se jedná o první takovéto zpracování většího území. Z výsledků je patrné, že řada rybníků existujících ve druhé polovině 18 . století do dnešní doby zanikla. Na druhou stranu je při porovnání se současným stavem území žrejmé, že od té doby vznikla raada nových. V následující fázi výzkumu budou dosažené výsledky využity především pro potřeby hodnocení postupného vývoje krajiny s ohledem na koncentraci a rozmístění vodních ploch v jednotlivých historických obdobích. Vytvořená vrstva může také posloužit při plánování výstavby malých vodních nádrží v zájmové oblasti formou obnovy zaniklých rybníků.

\section{Poděkování}

Výzkum prezentovaný v tomto článku byl realizován v rámci výzkumného projektu NAKI II DG16P02M036 „Údržba, opravy a monitoring hrází historických rybníků jako našeho kulturního dědictvi" financovaného Ministerstvem kultury České republiky.

\section{Literatura}

[1] MÍKA, A. a ŠTOCHL, S. Naše rybníky a prehradní jezera. Praha: Orbis, 1963, 256 s. [2] LIEBSCHER, P. a RENDEK, J. Rybníky České republiky. Praha: Academia, 2014, 584 s. [3] POKORNÝ, J., ZYKMUND, A., MAREŠ, J., LUSK, S., ŠILHAVÝ, V., SPURNÝ, P., SMOLEK, P., LEVÝ, E., ZAJIČEK, J. a MERTEN, M. České rybníky a rybářství ve 20. století. České Budějovice: Rybářské sdružení České republiky, 2015, 335 s.

[4] ANDRESKA, J. Lesk a sláva českého rybáŕství. 1. vyd. Praha: NUGA, 1997, 166 s.

[5] VLČEK, V. Zeměpisný lexikon ČSR - Vodní toky a nádrže. Praha: Academia, 1984, 315 s.

[6] KŘ́íVÁNEK, J., NĚMEC, J. a KOPP, J. Rybníky v České republice. Praha: Jan Němec - Consult, 2012, 303 s. [7] ZIMOVÁ, R., PEŠTÁK, J., and VEVERKA, B. Historical military mapping of the Czech lands-Cartographic Analysis. In: International Conference on Cartography and GIS. Borovets, Bulgaria, 2006, p. 1-7.

[8] PAVELKOVÁ, R., FRAJER, J., HAVLIČEK, M., NETOPIL, P., ROZKOŠNÝ, M., DAVID, V., DZURÁKOVÁ, M., and ŠARAPATKA, B. Historical ponds of the Czech Republic: an example of the interpretation of historic maps. Journal of Maps, 2016, 12(sup1), p. 551-559.

[9] PAVLEKOVÁ CHMELOVÁ, R., FRAJER, J. a NETOPIL, P. Historické rybníky České republiky: Srovnáni současnosti se stavem v2. polovině 19. století. Praha: Vúv TGM, v. v. i., 2014.

[10] VAŠKU゚, Z. Doba úpadku českého rybnikářství a hlavní vlny rušení rybníků. In: Gergel, J. a Hule, M. eds. Z historie českých rybníků. Praha: Výzkumný ústav meliorací a ochrany půdy, 1995, $45 \mathrm{~s}$.

[11] BOGUSZAK, F. a CíSAŘ, J. Vývoj mapového zobrazení území Československé socialistické republiky, III. díl-Mapování a měrení českých zemí od poloviny 18. stoleti do počátku 20. století. Praha: Ústřední správa geodézie a kartografie, 1961.

[12] MIKŠOVSKÝ, M. and ZIMOVÁ, R. Mapping of Czech lands during the $18^{\text {th }}$ century. In: Mapping Approaches into a Changing World. Proceedings of the XXII International Cartographic Conference, 2005, No. 53.

[13] HAVL [ČEK, M, SKOKANOVÁ, H. DAVID, V, PAVELKOVÁ, R, LÉTAL, A, FRAJER, J, NETOPIL, P. a ŠARAPATKA B. Možnosti využití starých topografických map z let 1763-1768 pro hodnocení vývoje vodních ploch a potenciál jejich obnovy. Vodohospodárské technicko-ekonomické informace, 2019, roč. 6, č. 1, s. 6-13.

[14] DAVID, V. a DAVIDOVÁ, T. Analýza vybraných morfologických charakteristik pro rybniční sítě ve čtyřech oblastech. Vodohospodářské technicko-ekonomické informace, 2017, roč. 59, č.1, 4-11.

[15] DYK, V., PODUBSKÝ, V. a ŠTĚDRONSKÝ, E. Naše rybářství. Praha: Práce, 1948, 450 s. 


\section{Autoři}

Ing. Václav David, Ph.D.

凶vaclav.david@fsv.cvut.cz

Ing. Kateřina Černochová

凶katerina.cernochova@fsv.cvut.cz

Katedra hydromeliorací a krajinného inženýrství, Fakulta stavební, České vysoké učení technické v Praze

Příspěvek prošel lektorským řízením.

\section{IDENTIFICATION OF PONDS IN THE BLANICE CATCHMENT AREA ON MAPS

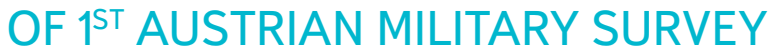

\section{DAVID, V.; CERNOCHOVA, K.}

Department of Hydromelioration and Landscape Engineering, Faculty of Civil Engineering, Czech Technical University in Prague

Keywords: fishpond - old maps - ${ }^{\text {st }}$ Austrian Military Survey identification - Blanice River

The article focuses on the identification of fishponds dawn on the maps of the $1^{\text {st }}$ Austrian Military Survey. The presented analyses are based mainly on manual work with old maps, because the maps used for the study lack the precision and detail needed for automated processing in the GIS environment. The study was carried out for the Blanice River basin with an area of $543.3 \mathrm{~km}^{2}$ located in the Central Bohemian Region $50 \mathrm{~km}$ southeast of Prague. Within the analyses, the location of each pond drawn on the maps of the $1^{\text {st }}$ Austrian Military Survey over the current maps was identified. A total of 818 ponds have been identified in the catchment area, of which 430 have been preserved to the present day. The result of the processing is a point layer of fishponds drawn on maps of $1^{\text {st }}$ Austrian Military Survey in ESRI shapefile format with attributes of accuracy of position determination and preservation of the dam body. 